Results: In total, 6062 patients with PsA were included, contributing 8172 treatment starts (table 1). SEC was mainly used as $2^{\text {nd }}$ or $\geq 3^{\text {rd }}$ line treatment. The survival curves and 1-year treatment retention rates, stratified by line of treatment, were similar for SEC compared to the TNFis, with some differences between the different TNFi (fig 1, table 2). Adjusted hazard ratios (HR) also indicated similar risk of SEC withdrawal compared to ADA (table 2).

Table 1. Patient characteristics at treatment start

\begin{tabular}{lllllll}
\hline & $1^{\text {st }}$ line & & $2^{\text {nd }}$ line & \multicolumn{3}{c}{$\geq 3^{\text {rd }}$ line } \\
& SEC & TNFi & SEC & TNFi & SEC & TNFi \\
& $\mathrm{N}=164$ & $\mathrm{~N}=3808$ & $\mathrm{~N}=273$ & $\mathrm{~N}=1767$ & $\mathrm{~N}=767$ & $\mathrm{~N}=1393$ \\
\hline Females & $48 \%$ & $47 \%$ & $44 \%$ & $42 \%$ & $36 \%$ & $39 \%$ \\
Age, years & $52(13)$ & $49(13)$ & $50(12)$ & $50(13)$ & $52(12)$ & $51(12)$ \\
Disease duration, years & $12(10)$ & $10(10)$ & $13(10)$ & $13(10)$ & $16(10)$ & $16(10)$ \\
Swollen joint count 28 & $3(4)$ & $2(3)$ & $2(3)$ & $2(3)$ & $3(4)$ & $2(3)$ \\
CRP, mg/L & $10(18)$ & $10(17)$ & $7(11)$ & $9(17)$ & $13(22)$ & $11(20)$ \\
Patient global score & $57(24)$ & $58(24)$ & $60(25)$ & $59(26)$ & $68(23)$ & $65(24)$ \\
Concomitant therapy & & & & & & \\
csDMARD & $30 \%$ & $60 \%$ & $41 \%$ & $57 \%$ & $49 \%$ & $53 \%$ \\
$\quad$ Methotrexate & $24 \%$ & $49 \%$ & $31 \%$ & $48 \%$ & $40 \%$ & $44 \%$ \\
Sulphasalazine & $2 \%$ & $9 \%$ & $5 \%$ & $5 \%$ & $4 \%$ & $6 \%$ \\
\hline
\end{tabular}

Numbers are mean (SD) unless noted otherwise

Table 2. One year treatment retention and hazard of discontinuation for SEC and TNF

\begin{tabular}{|c|c|c|c|c|}
\hline $\begin{array}{l}\text { Line of } \\
\text { treatment }\end{array}$ & Drug & $\mathbf{N}$ & $\begin{array}{l}1 \text { year treatment reten- } \\
\text { tion } \%(95 \% \mathrm{Cl})\end{array}$ & $\begin{array}{l}\text {-Adjusted HR }(95 \% \mathrm{Cl}) \\
\text { for discontinuation }\end{array}$ \\
\hline \multirow[t]{6}{*}{$1^{\text {st }}$ line } & ADA & 569 & $73(69-76)$ & Ref \\
\hline & CZP & 273 & $66(60-72)$ & $1.2(0.9-1.6)$ \\
\hline & ETN & 1747 & $73(71-75)$ & $0.9(0.7-1.1)$ \\
\hline & GOL & 212 & 67 (60-73) & $1.2(0.9-1.7)$ \\
\hline & IFX & 1007 & $62(59-65)$ & $1.4(1.1-1.7)$ \\
\hline & SEC & 164 & $72(63-78)$ & $1.0(0.7-1.4)$ \\
\hline \multirow[t]{6}{*}{$2^{\text {nd }}$ line } & ADA & 415 & $69(63-73)$ & Ref \\
\hline & CZP & 176 & $51(43-58)$ & $1.6(1.2-2.2)$ \\
\hline & ETN & 701 & $63(59-66)$ & $1.2(0.9-1.5)$ \\
\hline & GOL & 151 & $69(61-76)$ & $0.9(0.6-1.2)$ \\
\hline & IFX & 324 & 65 (59-70) & $1.0(0.8-1.4)$ \\
\hline & SEC & 273 & $69(62-74)$ & $0.9(0.7-1.2)$ \\
\hline \multirow[t]{6}{*}{$\geq 3^{\text {rd }}$ line } & ADA & 346 & $67(62-72)$ & Ref \\
\hline & CZP & 221 & $49(42-56)$ & $1.5(1.2-2.0)$ \\
\hline & ETN & 372 & $62(57-67)$ & $1.1(0.9-1.5)$ \\
\hline & GOL & 206 & $56(49-63)$ & $1.3(1.0-1.8)$ \\
\hline & IFX & 248 & $57(50-63)$ & $1.3(1.0-1.8)$ \\
\hline & SEC & 767 & $63(59-67)$ & $1.0(0.8-1.3)$ \\
\hline
\end{tabular}

Conclusion: In this large study of bDMARD treatment of PsA in clinical practice, SEC was most often used as $2^{\text {nd }}$ or $\geq 3^{\text {rd }}$ line treatment, and the treatment retention of SEC was comparable with that of TNFi. Further analyses, taking into account other comorbidities, channeling and effectiveness will be presented.

Figure 1. Treatment retention for secukinumab and TNFi, stratified by $1^{\text {st }}, 2^{\text {nd }}$ and $\geq 3^{\text {rd }}$ line of treatment.
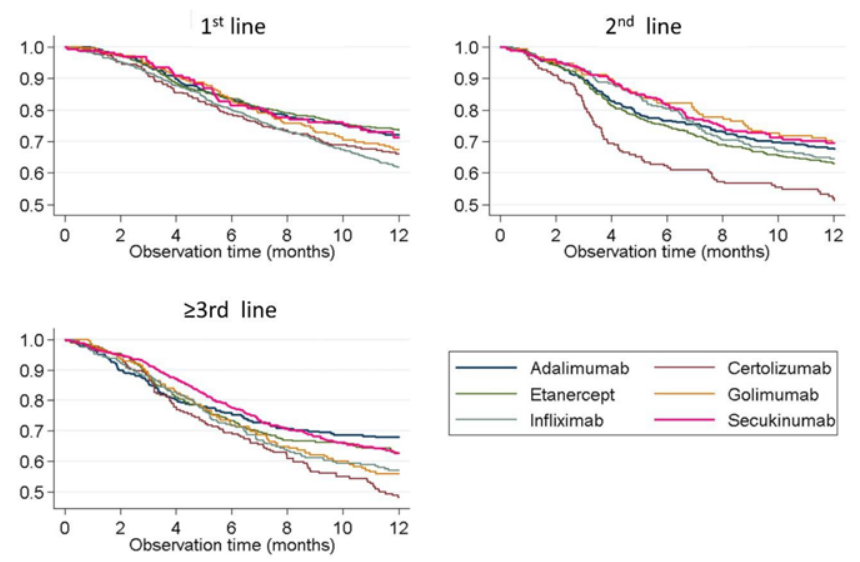

Acknowledgments: UL and BG are shared first, and LJ and LEK shared last authors.

Partly funded by Nordforsk and FOREUM.
Disclosure of Interests: Ulf Lindström: None declared, Bente Glintborg Grant/ research support from: Grants from Pfizer, Biogen and Abbvie, Daniela Di Giuseppe: None declared, Tanja Schjødt Jørgensen Speakers bureau: Abbvie, Pfizer, Roche, Novartis, UCB, Biogen, and Eli Lilly

, Björn Gudbjornsson Speakers bureau: Novartis and Amgen, Kathrine L. Grøn Grant/research support from: BMS, Sella Aarrestad Provan Consultant of: Novartis, Brigitte Michelsen: None declared, Merete L. Hetland Grant/research support from: BMS, MSD, AbbVie, Roche, Novartis, Biogen and Pfizer, Consultant of: Eli Lilly, Speakers bureau: Orion Pharma, Biogen, Pfizer, CellTrion, Merck and Samsung Bioepis, Johan K Wallman Consultant of: AbbVie, Celgene, Eli Lilly, Novartis and UCB Pharma, Dan Nordström Consultant of: Abbvie, Celgene, Lilly, Novartis, Pfizer, Roche and UCB., Speakers bureau: Abbvie, Celgene, Lilly, Novartis, Pfizer, Roche and UCB., Nina Trokovic: None declared, Thorvardur Love: None declared, Niels Steen Krogh: None declared, Johan Askling Grant/ research support from: JA acts or has acted as PI for agreements between Karolinska Institutet and the following entities, mainly in the context of the ARTIS national safety monitoring programme of immunomodulators in rheumatology: Abbvie, BMS, Eli Lilly, Merck, MSD, Pfizer, Roche, Samsung Bioepis, Sanofi, and UCB Pharma, Lennart T.H. Jacobsson Consultant of: AbbVie, Eli Lilly, Janssen, Novartis and Pfizer, Lars Erik Kristensen Consultant of: UCB Pharma (Advisory Board), Sannofi (Advisory Board), Abbvie (Advisory Board), Biogen (Advisory Board), Speakers bureau: AbbVie, Amgen, Biogen, Bristol-Myers Squibb,Celgene, Eli Lilly, Gilead, Forward Pharma, Janssen Pharmaceuticals, MSD, Novartis, Pfizer, and UCB Pharma DOI: 10.1136/annrheumdis-2020-eular.881

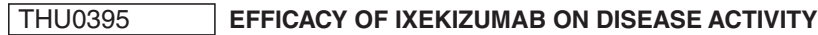 AND QUALITY OF LIFE IN PATIENTS WITH ACTIVE NON-RADIOGRAPHIC AXIAL SPONDYLOARTHRITIS AND OBJECTIVE SIGNS OF INFLAMMATION, STRATIFIED BY BASELINE CRPISACROILIAC JOINT MRI STATUS}

W. P. Maksymowych ${ }^{1}$, H. Marzo-Ortega ${ }^{2}$, M. Ǿstergaard ${ }^{3}$, L. S. Gensler ${ }^{4}$ J. Ermann ${ }^{5}$, A. Deodhar ${ }^{6}$, D. Poddubnyy ${ }^{7}$, D. Sandoval ${ }^{8}$, R. Bolce ${ }^{8}$,

A. Kronbergs ${ }^{8}$, S. Liu Leage ${ }^{8}$, G. Doridot ${ }^{8}$, V. Geneus ${ }^{8}$, A. Leung ${ }^{9}$, D. Adams ${ }^{8}$,

M. Rudwaleit ${ }^{10,11}$. ' University of Alberta, Edmonton, Canada; ${ }^{2}$ NIHR LBRC, LTHT and University of Leeds, Leeds, United Kingdom; ${ }^{3}$ University of Copenhagen,

Copenhagen, Denmark; ${ }^{4}$ University of California San Francisco, San Francisco, United States of America; ${ }^{5}$ Brigham and Women's Hospital, Boston, United States of America; ${ }^{6}$ Oregon Health \& Science University, Portland, United States of America; ${ }^{7}$ Charité Universitätsmedizin Berlin, Berlin, Germany; ${ }^{8}$ Eli Lilly and Company, Indianapolis, United States of America; ${ }^{9}$ Syneos Health, Morrisville, United States of America; ${ }^{10}$ Klinikum Bielefeld, Bielefeld, Germany;

${ }^{11}$ Charité Universitätsmedizin Berlin, Berlin, Germany

Background: Ixekizumab (IXE), a high-affinity anti-interleukin-17A monoclonal antibody, is effective in patients (pts) with active non-radiographic axial spondyloarthritis (nr-axSpA), who had elevated C-reactive protein (CRP) and/or active sacroiliitis on magnetic resonance imaging (MRI). ${ }^{1}$

Objectives: To determine if disease activity and patient-reported outcomes at Week 16 were similar between groups after stratifying pts by CRP/sacroiliac joint (SIJ) MRI status at baseline.

Methods: COAST-X (NCT02757352) included pts with active nr-axSpA and objective signs of inflammation, i.e. presence of sacroiliitis on MRI (Assessment of Spondyloarthritis International Society [ASAS]/ Outcome Measures in Rheumatology criteria) or elevation of serum CRP $(>5.0 \mathrm{mg} / \mathrm{L})$. Pts were randomized 1:1:1 to receive subcutaneous $80 \mathrm{mg}$ IXE every 4 weeks (Q4W) or Q2W, or placebo (PBO). Depending on the baseline values of CRP and MRI SIJ (Spondyloarthritis Research Consortium of Canada [SPARCC] score), pts in the intent-to-treat population $(\mathrm{N}=239)$ were divided into 3 subgroups (CRP $>5$ and $\mathrm{MRI} \geq 2 ; \mathrm{CRP} \leq 5$ and $\mathrm{MRI} \geq 2$; CRP $>5$ and $\mathrm{MRI}<2$ ). Logistic regression analysis with treatment, subgroup, and treatment-by-subgroup interaction was used to detect treatment group differences in ASAS40, Ankylosing Spondylitis Disease Activity Score (ASDAS) <2.1 (low disease activity), and Bath Ankylosing Spondylitis Disease Activity Index 50 (BASDAI50) responses at Week 16. Analysis of covariance model with baseline value, treatment, subgroup, and treatment-by-subgroup interaction was used to detect the treatment group difference in change from baseline in Short Form-36 physical component score (SF-36 PCS).

Results: The proportion of pts achieving ASAS40 (primary endpoint), ASDAS $<2.1$, and BASDAI50 (secondary endpoints) was higher in IXE treatment groups compared to $\mathrm{PBO}$ at Week 16 (Figure 1). The response rates in IXE-treated subjects were higher in all subgroups (CRP $>5$ and MRI $\geq 2 ; \mathrm{CRP} \leq 5$ and MRI $\geq 2$; $C R P>5$ and $M R I<2$ ) without consistent differences in efficacy between the subgroups. Similarly, pts in the IXE groups showed improvement in SF-36 PCS scores (secondary endpoint) versus pts on PBO at Week 16 (Figure 2). 
Conclusion: Pts with active nr-axSpA and objective signs of inflammation at baseline who were treated with IXE showed an overall improvement in the signs and symptoms of the disease. The efficacy was not different between pts with both elevated CRP and active sacroiliitis on MRI and pts with either elevated CRP or active sacroiliitis on MRI.

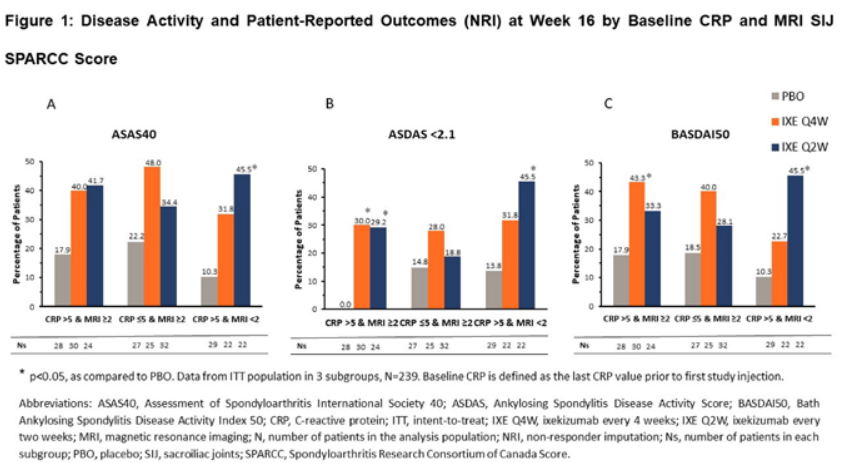

Figure 2: Change from Baseline in SF-36 PCS Score at Week 16 by Baseline CRP and MRI SIJ SPARCC Score

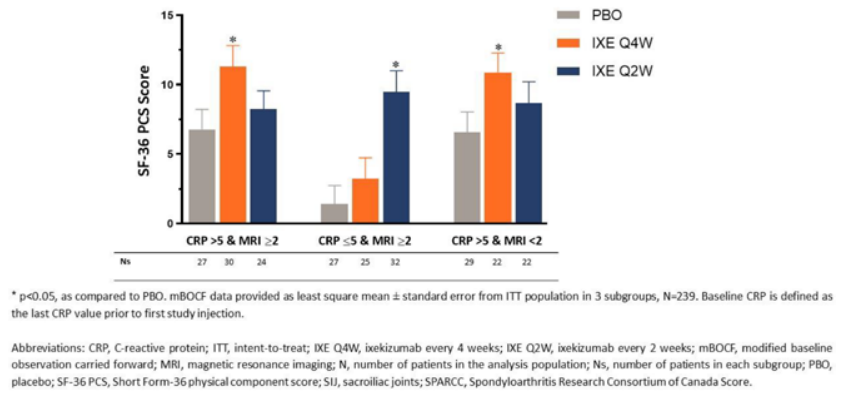

References:

[1] Deodhar A, et al. Lancet. 2020.

Disclosure of Interests: Walter P Maksymowych Grant/research support from: Received research and/or educational grants from Abbvie, Novartis, Pfizer, UCB, Consultant of: WPM is Chief Medical Officer of CARE Arthritis Limited, has received consultant/participated in advisory boards for Abbvie, Boehringer, Celgene, Eli-Lilly, Galapagos, Gilead, Janssen, Novartis, Pfizer, UCB, Speakers bureau: Received speaker fees from Abbvie, Janssen, Novartis, Pfizer, UCB., Helena Marzo-Ortega Grant/research support from: Janssen, Novartis, Consultant of: Abbvie, Celgene, Eli Lilly, Janssen, Novartis, Pfizer, UCB, Speakers bureau: Abbvie, Celgene, Eli Lilly, Janssen, Novartis, Pfizer, Takeda, UCB, Mikkel Ǿstergaard Grant/research support from: AbbVie, Bristol-Myers Squibb, Celgene, Merck, and Novartis, Consultant of: AbbVie, Bristol-Myers Squibb, Boehringer Ingelheim, Celgene, Eli Lilly, Hospira, Janssen, Merck, Novartis, Novo Nordisk, Orion, Pfizer, Regeneron, Roche, Sandoz, Sanofi, and UCB, Speakers bureau: AbbVie, Bristol-Myers Squibb, Boehringer Ingelheim, Celgene, Eli Lilly, Hospira, Janssen, Merck, Novartis, Novo Nordisk, Orion, Pfizer, Regeneron, Roche, Sandoz, Sanofi, and UCB, Lianne S. Gensler Grant/research support from: Pfizer, Novartis, UCB, Consultant of: AbbVie, Eli Lilly, GSK, Novartis, UCB, Joerg Ermann Grant/research support from: Boehringer-Ingelheim, Pfizer, Consultant of: Abbvie, Eli Lilly, Janssen, Novartis,

Pfizer, Takeda, UCB, Atul Deodhar Grant/research support from: AbbVie, Eli Lilly, GSK, Novartis, Pfizer, UCB, Consultant of: AbbVie, Amgen, Boehringer Ingelheim, Bristol Myer Squibb (BMS), Eli Lilly, GSK, Janssen, Novartis, Pfizer, UCB, Speakers bureau: AbbVie, Amgen, Boehringer Ingelheim, Bristol Myer Squibb (BMS), Eli Lilly, GSK, Janssen, Novartis, Pfizer, UCB, Denis Poddubnyy Grant/research support from: AbbVie, MSD, Novartis, and Pfizer, Consultant of: AbbVie, Bristol-Myers Squibb, Eli Lilly, MSD, Novartis, Pfizer, Roche, UCB, Speakers bureau: AbbVie, Bristol-Myers Squibb, Eli Lilly, MSD, Novartis, Pfizer, Roche, UCB, David Sandoval Shareholder of: Eli Lilly and Company, Employee of: Eli Lilly and Company, Rebecca Bolce Shareholder of: Eli Lilly and Company, Employee of: Eli Lilly and Company, Andris Kronbergs Shareholder of: Eli Lilly and Company, Employee of: Eli Lilly and Company, Soyi Liu Leage Shareholder of: Eli Lilly and Company, Employee of: Eli Lilly and Company, Gabriel Doridot Shareholder of: Eli Lilly and Company, Employee of: Eli Lilly and Company,
Vladimir Geneus Shareholder of: Eli Lilly and Company, Employee of: Eli Lilly and Company, Ann Leung: None declared, David Adams Shareholder of: Eli Lilly and Company, Employee of: Eli Lilly and Company, Martin Rudwaleit Consultant of: AbbVie, BMS, Celgene, Janssen, Eli Lilly, MSD, Novartis, Pfizer, Roche, UCB Pharma

DOI: 10.1136/annrheumdis-2020-eular.2027

\section{THU0396 \\ IMPACT OF IXEKIZUMAB ON WORK PRODUCTIVITY IN PATIENTS WITH ANKYLOSING SPONDYLITIS: RESULTS FROM THE COAST-V AND COAST-W TRIALS AT 52 WEEKS}

H. Marzo-Ortega ${ }^{1}$, P. J. Mease ${ }^{2}$, P. Rahman ${ }^{3}$, V. Navarro-Compán ${ }^{4}$, V. Strand ${ }^{5}$, M. Dougados ${ }^{6}$, B. Combe ${ }^{7}$, J. C. C. Wei ${ }^{8}$, X. Baraliakos ${ }^{9}$, T. Hunter $^{10}$, D. Sandoval ${ }^{10}$, X. LI $^{10}$, B. Zhu ${ }^{10}$, L. Bessette ${ }^{11}$, A. Deodhar ${ }^{12} .{ }^{1}$ University of Leeds, West Yorkshire, United Kingdom; ${ }^{2}$ Swedish Medical Center/Providence St. Joseph Health and University of Washington, Seattle, United States of America; ${ }^{3}$ Memorial University of Newfoundland, St. John's, Canada; ${ }^{4}$ Hospital Universitario La Paz IdiPaz, Madrid, Spain; ${ }^{5}$ Stanford University School of Medicine, Palo Alto, United States of America; ${ }^{6}$ Cochin Hospital, Paris, France; ${ }^{7} \mathrm{CHU}$ Montepellier and Montpellier University, Montpellier, France; ${ }^{8} \mathrm{China}$ Medical University, Taichung City, Taiwan, Republic of China; ${ }^{9}$ St. Elisabeth Group, GmbH, Herne, Germany; ${ }^{10}$ Eli Lilly and Company, Indianapolis, United States of America; " ${ }^{11}$ Laval University and CHU de Quebec, Quebec City, Canada; ${ }^{12}$ Oregon Health \& Science University, Portland, United States of America

Background: Patients with ankylosing spondylitis (AS) are burdened with decreased work productivity. ${ }^{1}$ Ixekizumab (IXE), a high-affinity monoclonal antibody selectively targeting interleukin-17A, has been shown to improve disease signs and symptoms in 2 phase 3 trials assessing patients with active $\mathrm{AS}^{2,3}$

Objectives: This study investigated the effect of IXE treatment for 52 weeks on work productivity and activity impairment as measured by absenteeism, presenteeism, overall work impairment, and activity impairment in patients with active AS.

Methods: COAST-V (NCT02696785) and COAST-W (NCT02696798) were phase 3 , multicenter, randomized, double-blind, placebo (PBO)-controlled (COAST-V active-controlled with adalimumab) trials investigating the efficacy of IXE every 4 weeks (Q4W) and every 2 weeks (Q2W) in 341 patients with active AS naïve to biologic disease-modifying antirheumatic drugs (bDMARDs; COAST-V) and in 316 patients who were inadequate responders or intolerant to 1 or 2 tumor necrosis factor inhibitors (TNFi; COAST-W). Patients receiving PBO were switched to IXE Q4W or Q2W at Week 16; patients receiving adalimumab (ADA) were switched to IXE Q4W or Q2W at Week 20. Data for IXE Q4W and Q2W were combined for PBO/IXE and ADA/IXE groups. Changes from baseline in work productivity were measured for those reporting full- or part-time work at Weeks 16 and 52 with the Work Productivity and Activity Impairment (WPAI) Questionnaire for Spondyloarthritis.

Results: Compared to bDMARD-naïve patients (COAST-V), TNFi-experienced patients (COAST-W) were slightly older, had longer disease duration, reported less paid employment, and had greater scores for impaired work productivity, signifying more severe baseline disease. At Week 16, bDMARD-naïve patients treated with IXE Q4W or Q2W had significant improvements in activity impairment compared to placebo $(p<0.01)$; TNFi-experienced patients treated with IXE Q4W or Q2W had significant improvements in presenteeism $(p<0.05)$ and overall work impairment $(p<0.05$; Figure). TNFi-experienced patients treated with IXE Q2W also had significant improvement in activity impairment at Week 16 ( $p<0.05$; Figure). Improvements were sustained through Week 52 (Figure).

Conclusion: Both bDMARD-naïve and TNFi-experienced patients with AS receiving IXE had greater improvements in aspects of work productivity compared to placebo. Improvements were sustained through Week 52.

\section{References:}

[1] Boonen, van der Linden. (2006). J Rheumatol Suppl. 78:4-11

[2] Van der Heijde, et al. (2018) Lancet. 392(10163):2441-51.

[3] Deodhar, et al. (2019) Arthritis Rheumatol. 71(4):599-611.

Disclosure of Interests: Helena Marzo-Ortega Grant/research support from: Janssen, Novartis, Consultant of: Abbvie, Celgene, Eli Lilly, Janssen, Novartis, Pfizer, UCB, Speakers bureau: Abbvie, Celgene, Eli Lilly, Janssen, Novartis, Pfizer, Takeda, UCB, Philip J Mease Grant/research support from AbbVie, Amgen, Bristol-Myers Squibb, Janssen, Eli Lilly, Novartis, Pfizer, Sun Pharma, UCB Pharma, Consultant of: AbbVie, Amgen, Bristol-Myers Squibb, Celgene, Janssen, Eli Lilly, Galapagos, Gilead, Novartis, Pfizer, Sun Pharma, 